\title{
Impedance Matching Method in Two-Stage Converters for Single Phase PV-Grid System
}

\author{
L. Heru Pratomo*,**, F. Danang Wijaya*, Eka Firmansyah* \\ * Departement of Electrical Engineering and Information Technology, Gadjah Mada University, Indonesia \\ ** Departement of Electrical Engineering, Soegijapranata Catholic University, Indonesia
}

\begin{tabular}{l} 
Article Info \\
\hline Article history: \\
Received Mar 16, 2015 \\
Revised May 6, 2015 \\
Accepted May 25, 2015 \\
\hline Keyword: \\
Buck-Boost DC-DC Converter \\
Five-Level Inverter \\
Impedance Matching \\
PV-Grid \\
Two-Stage Converters
\end{tabular}

\section{Corresponding Author:}

L. Heru Pratomo,

Departement of Electrical Engineering and Information Technology,

Gadjah Mada University,

Jl. Grafika No 2. Kampus UGM, Yogyakarta, 55281, Indonesia.

Email: heru.s3te12@mail.ugm.ac.id

\begin{abstract}
This paper presents the study on the impedance matching method in twostage converters for single phase PV-grid system. The use of PV systems was to obtain the electrical power from the sunlight energy. The system consisted of a Buck-Boost DC-DC converter and a five-level inverter. A Buck-Boost DC-DC converter was used as a means of impedance matching to obtain the maximum power that, in this case, through a method by using the incremental conductance current control algorithm. Meanwhile a five-level inverter was used as an interface to the utilities. By using this technique, the system came to be simple. The impedance of the power grid, a Buck-Boost DC-DC converter, and a five-level inverter were seen by PV mostly in the area of $\mathrm{R}_{\mathrm{MPP}}$, enabling the maximum power produced by the PV to be delivered to the grid. To demonstrate the effectiveness of the design, the analysis and simulation results, furthermore, were provided.
\end{abstract}

Copyright (c) 2015 Institute of Advanced Engineering and Science. All rights reserved.

\section{INTRODUCTION}

A solar energy were clean and free of pollution, this energy directly converts into electrical energy known as the Photovoltaic (PV), this device generate electricity without producing $\mathrm{CO}^{2}$. The trend of PV utilization recently is growing very rapidly as seen in several applications such as residences, offices and industries. The PV-grid system has many advantages [1, 2], one of which is to enhance the installed power in the anticipation of the peak load, for example.

The PV-Grid system has been researched since two last decades are alternative ways to deliver active power to the grid. Active power delivery techniques have been investigated $[3,4]$ and to make it more affordable, practical and more compact connection system uses a technique without transformers. The power utilization system is together proven to be; thus, the load is borne by the more lightly [5]. The magnitude of power brought into the correlation magnitude of current is then sent through the current source inverter and it is proven to transmit power to the grid [6, 7]. In the PV system, a Buck-Boost DC-DC converter used as an MPPT (maximum power point tracker) is used to obtain the maximum power [8-10]. The PV-grid system consists of two-stage converter, the fist converter usually used a DC-DC converter act as MPPT and the second one is inverter to produce an output current in phase with the grid voltage and to obtain a unity power factor [11-16]. The goal idea of this topology was easier to transmit active power to the grid using a voltage source inverter. The problem with this concept, there are many of controller design and much of sensors on inverter side. Thus, the system has poor efficiency, due to a large number of devices, excessive size, heavy weight, and high cost. 
Different from the concept that has been described; the impedance matching method in two-stage converters for single phase PV-grid system will be proposed in this paper. PV had a nonlinear characteristic curve, the load would be seen by the PV mostly be in the area $\mathrm{R}_{\mathrm{MPP}}$ (maximum power point). By exploiting this method, an impedance of the grid, a five-level inverter and a Buck-Boost DC-DC converter has been always certain to be at the point of $\mathrm{R}_{\mathrm{MPP}}$. Thereby, it was possible to perform a maximum power delivery. This control method can reduce the amount of complicated control, thus making the proposed control system highly simple. Furthermore, the analysis and computer simulations have been conducted to obtain the expected accurate results.

\section{RESEARCH METHOD}

Photovoltaic or PV refers to a device that can directly convert the sunlight energy. The work principle of the PV will produce a maximum power as seen in Figure 1. An incremental conductance current control method works based on the exploration of the power Vs voltage curve. The power will be maximized when satisfying the following equation [10]:

$$
\begin{aligned}
& \left(\frac{d P}{d V}\right)_{M P P}=\frac{d\left(V_{P V} I_{P V}\right)}{d V_{P V}} \\
& I_{P V} \frac{d V_{P V}}{d V_{P V}}+V_{P V} \frac{d I_{P V}}{d V_{P V}}=0 \\
& I_{P V}=-V_{P V} \frac{d I_{P V}}{d V_{P V}}
\end{aligned}
$$

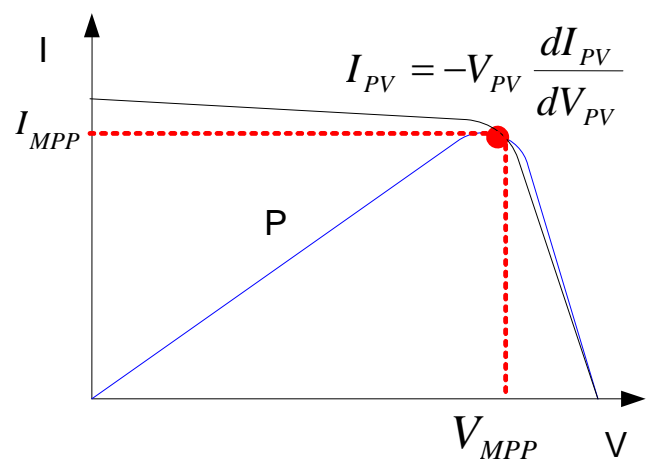

Figure 1. P-V curve to obtain maximum power point

As shown in Figure 2, PV had a unique characteristic load. Since the loading curve directly resulting in the curve was not defined at maximum power, the PV system required a converter as impedance matching.

The PV-grid system consists of two-stage converter, the fist converter is a Buck-Boost DC-DC converter and the second one is a five-level inverter. In this section will be derived a power delivery technique based on impedance matching in two-stage converter. A five-level inverter was used as an interface to the grid to deliver the maximum power to the grid, Figure 3. It had an advantage in terms of harmonic output reduction [17]. The magnitude of the output voltage was affected by the magnitude of the modulation index by the following equation:

$$
V_{o}=I_{m} V_{i}
$$

Where:

$$
I_{m}=\frac{A_{\text {inf }}}{A_{c a r}}=\text { Modulation index }
$$


$A_{\text {inf }}=$ The amplitude of the signal information

$A_{c a r}=$ The amplitude of the signal carrier

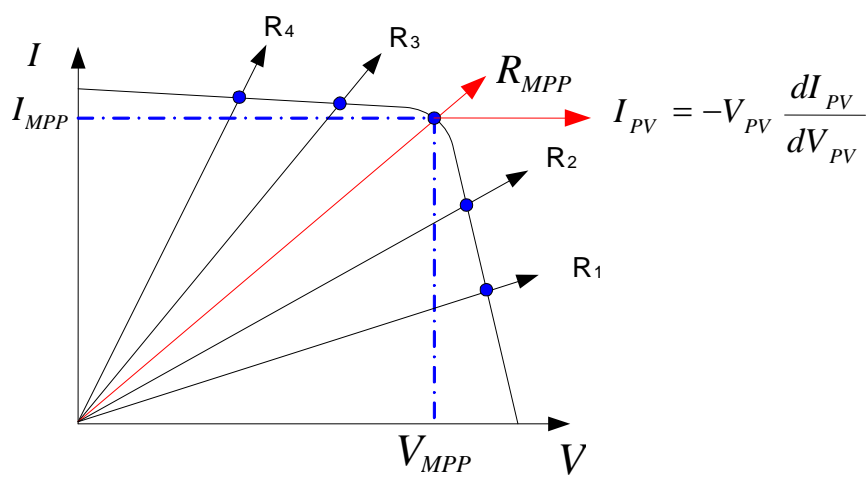

Figure 2. PV characteristic curve for loading directly

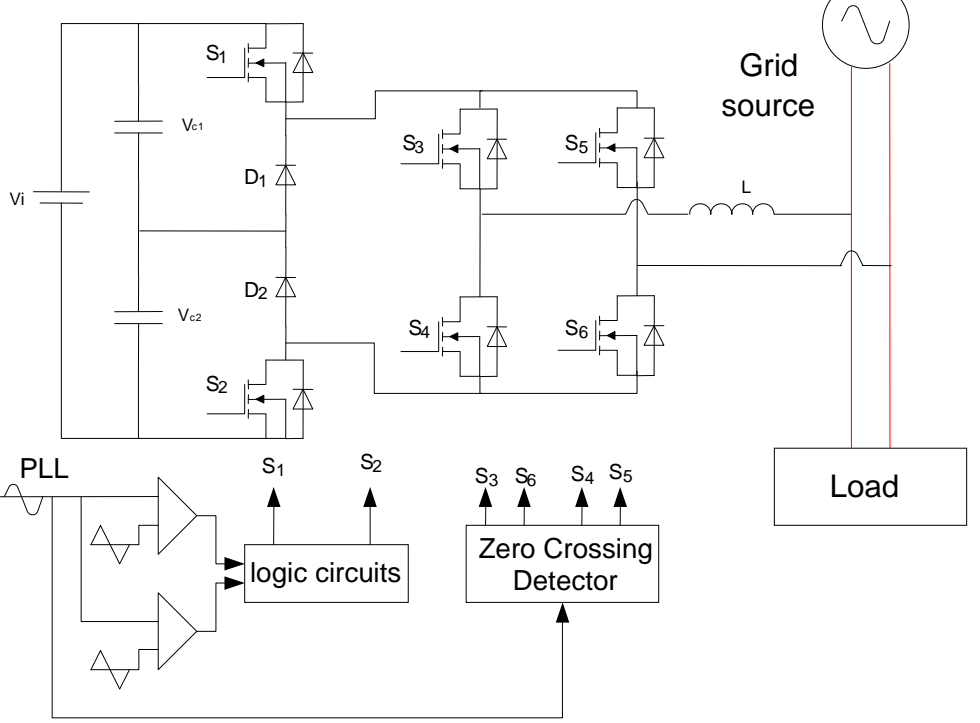

Figure 3. Five-level inverter scheme

By considering the similarity law in the power output and input,

$$
\begin{aligned}
& P_{o}=V_{o} I_{o} \\
& P_{i}=V_{i} I_{i}
\end{aligned}
$$

Thus, equality law power on the input side and the output could be obtained as the similarities:

$$
\begin{aligned}
& V_{i} I_{i}=V_{o} I_{o}, \\
& V_{i} \frac{V_{i}}{Z_{i}}=I_{m} V_{i} \frac{I_{m} V_{i s}}{Z_{o}}
\end{aligned}
$$

Thus, the impedance matching based on modulation index equation, as follows: 


$$
\frac{Z_{o}}{I_{m}{ }^{2}}=Z_{i}
$$

If the magnitude of the modulation index was equal to one, the impedance equation began:

$$
Z_{o}=Z_{i}
$$

A Buck-Boost DC-DC converter is used for impedance matching. The scheme of Buck-Boost DCDC converter is shown in Figure 4. From the mode of operation of Buck-Boost DC-DC converter, it can be derived an equation impedance matching as a function of the duty cycle.

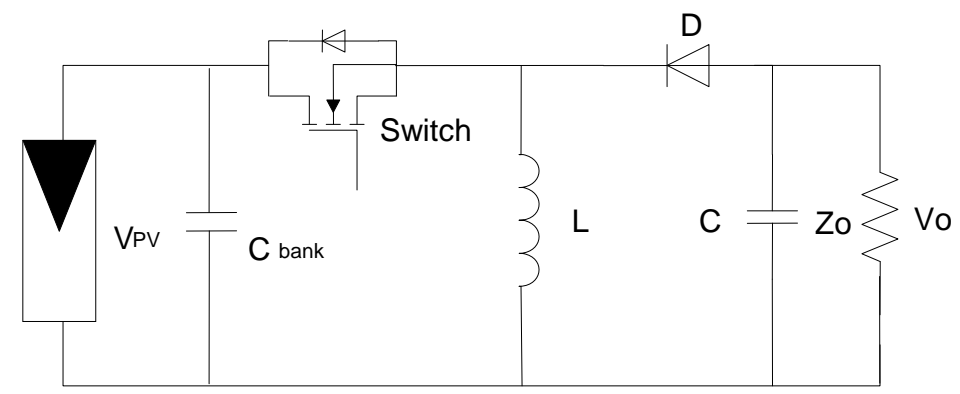

Figure 4. Buck-Boost DC-DC converter scheme

A Buck-Boost DC-DC Converter has two modes of operation. The mode of operation 1: electronic switch is ON: the current flow from PV to the inductor (L) and get back to the negative terminal. From this operation mode has an equation:

$$
V_{P V}=L \frac{d i}{d t}
$$

The mode of operation 2: electronic switch is OFF: the current flow from the inductor (L) to the load and get back to the inductor (L). From this operation mode has an equation:

$$
L \frac{d i}{d t}=V_{o}
$$

From equation (8) and (9), the magnitude of the output voltage was affected by the magnitude of the duty cycle by the following equation:

$$
\frac{V_{o}}{V_{P V}}=\frac{d}{1-d}
$$

Where:

$$
\begin{aligned}
& d=\frac{t_{\text {on }}}{T}=\text { Duty cycle } \\
& t_{\text {on }}=\text { Time ON of the electronic switch } \\
& T=\text { Switching period }
\end{aligned}
$$

By considering the similarity law in the power output (3) and input (4), equality law power on the input side and the output side were be obtained as the similarities: 


$$
\begin{aligned}
& V_{P V} I_{P V}=V_{o} I_{o} \\
& V_{P V} \frac{V_{P V}}{R_{P V}}=\frac{d}{1-d} V_{P V} \frac{\frac{d}{1-d} V_{P V}}{Z_{o}} \\
& \frac{V_{P V}{ }^{2}}{R_{P V}}=\frac{\left[\frac{d}{1-d}\right]^{2} V_{P V}^{2}}{Z_{o}}
\end{aligned}
$$

Thus, the impedance matching based on duty cycle equation, as follows:

$$
\frac{Z_{o}}{\left[\frac{d}{1-d}\right]^{2}}=R_{P V}=R_{M P P}
$$

Hence, a five-level inverter and Buck-Boost DC-DC converter would have the equivalent circuit as impedance matching is shown in Figure 5.

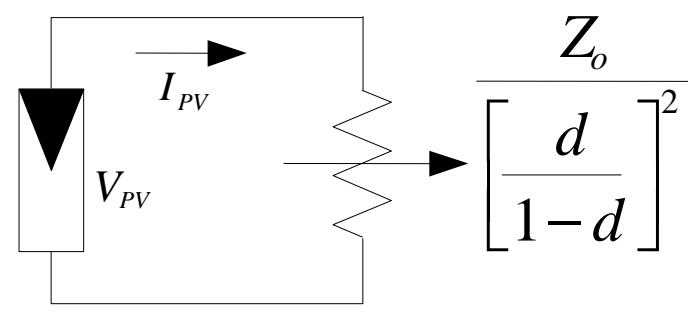

Figure 5. Equivalent circuit of two-stage converter

Thus, the grid impedance, a five-level inverter and Buck-Boost DC-DC converter came to always be at the point $\mathrm{R}_{\mathrm{MPP}}$, and the maximum power was always being delivered to the grid of PV system.

Figure 6 presents the proposed scheme model of the impedance matching method for two-stage converter in PV-grid system, that consisted of a Buck-Boost DC-DC converter functioned as maximum power point tracker and a five-level inverter used as an interface to the grid. To perform the analysis of the proposed system, a simulation platform has been designed. Figure 6 shows the simulation scheme of the single phase PV-grid system to deliver active power from PV modules.

Here is a correlation of power on PV modules, Buck-Boost converter and a five-level inverter. If the grid voltage $V_{\text {Grid }}$ and output current inverter $I_{\text {inv }}$, the instantaneous power was injected to the grid, expressed as

$$
p_{\text {inv }}(t)=v_{\text {Grid }}(t) \cdot i_{i n v}(t)
$$

And the average power could be found as

$$
P_{i n v}=\int_{0}^{T} p_{i n v}(t) d t
$$

When current and voltage, which in phase, the average power could be calculated by using the RMS value of current and voltage, thus

$$
P_{i n v}=V_{\text {grid }} \cdot I_{i n v}
$$




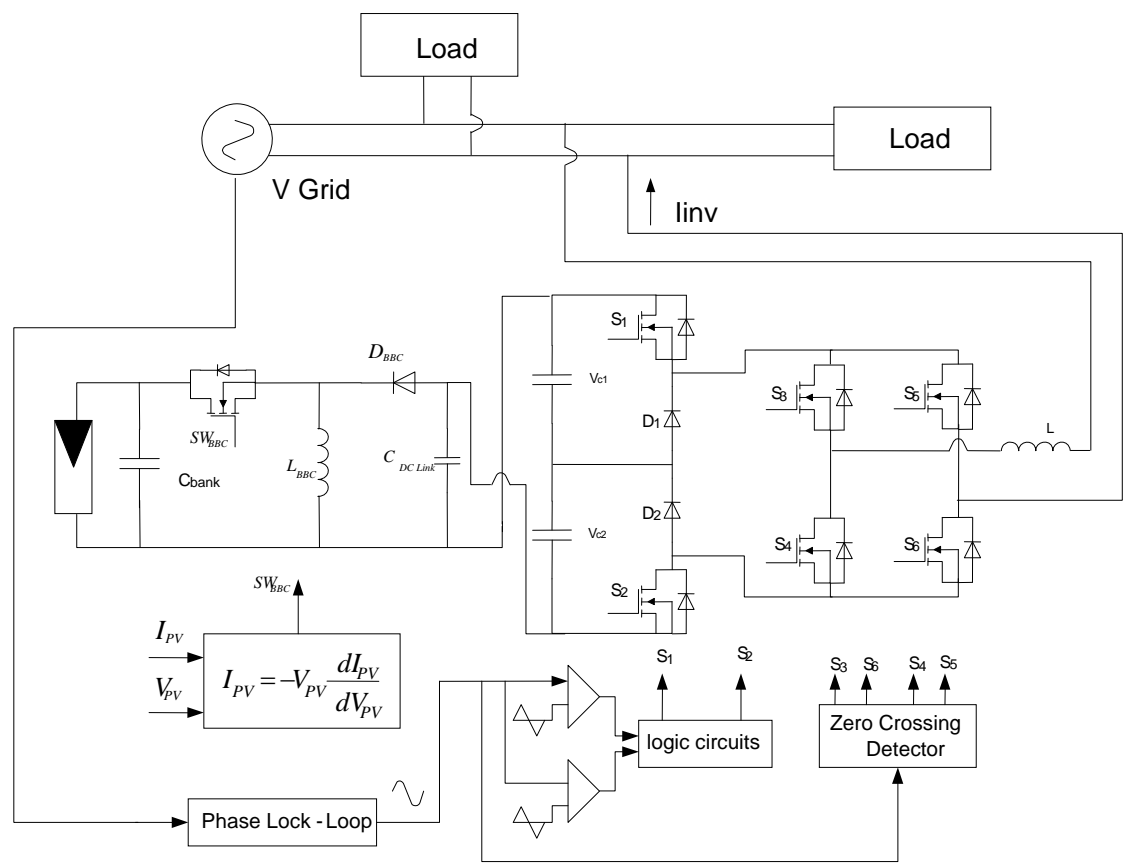

Figure 6. Proposed scheme

In ideal condition, the average power of injected power had the same value of PV power

$$
P_{P V}=P_{D C-D C}=P_{i n v}
$$

For these conditions, inverter output current can be expressed as

$$
\begin{aligned}
& I_{\text {inv }}=\frac{V_{M P P} I_{M P P}}{V_{\text {Grid }}}=\frac{P_{D C-D C}}{V_{\text {Grid }}} \\
& I_{\text {inv }}=\frac{P_{D C-D C}}{V_{\text {Grid }}}
\end{aligned}
$$

The important thing must be understood by comparing the value of power: instantaneous power and average power. Buck-Boost DC-DC converter operated under instantaneous power and five-level operated under average power. For the controller operated under instantaneous power condition, it is needed a capacitor dc link for energy storage element, which is installed between five-level inverter and Buck-Boost DC-DC converter. When instantaneous power of five-level inverter output is greater than power generated by Buck-Boost DC-DC converter, the energy stored in the capacitor would be released. The opposite condition happens when the instantaneous power of five-level inverter output is less than power generated by BuckBoost DC-DC converter, this would make a capacitor absorbs power from Buck-Boost DC-DC converter.

The load was constructed using a resistor. AC link inductor at the five-level inverter used to attenuate the switching ripple to prevent high harmonics switching frequency. The phase lock-loop was used for synchronization between a five-level inverter with a single phase grid system to obtain a maximal power delivery.

\section{RESULTS AND ANALYSIS}

Verification of the analysis that has been conducted was performed, though simulation. Simulation works were based on Power Simulator software by using the scheme depicted in Figure 6. Table 1 presents the parameter used in the simulation. The PV-grid system contains resistive and five-level inverter was connected to the grid to deliver active power. 
Table 1. The performance of simulation

\begin{tabular}{lc}
\hline \multicolumn{1}{c}{ Parameters } & Value \\
\hline Pmax & $50.45 \mathrm{WP}$ \\
Current at Pmax & $14.2 \mathrm{~V}$ \\
Voltage at Pmax & $3.55 \mathrm{~A}$ \\
Number of Modules in Array & 12 \\
Modules Connection & Series \\
Grid Voltage & $220 \mathrm{~V}_{\mathrm{rms}}$ \\
Inductor & $2.5 \mathrm{mH}$ \\
Switching Frequency & $20 \mathrm{KHz}$ \\
\hline
\end{tabular}

When solar irradiance under $1000 \mathrm{~W} / \mathrm{m}^{2}$ with resistive load $10 \mathrm{Ohm}$, the maximum power would be produced by PV, the required power to the load is very large; the load power would be supplied by the power generated by PV and single phase grid source. In other hand; load, inverter and the grid source current would be in phase respect with the grid voltage, Figure 7.

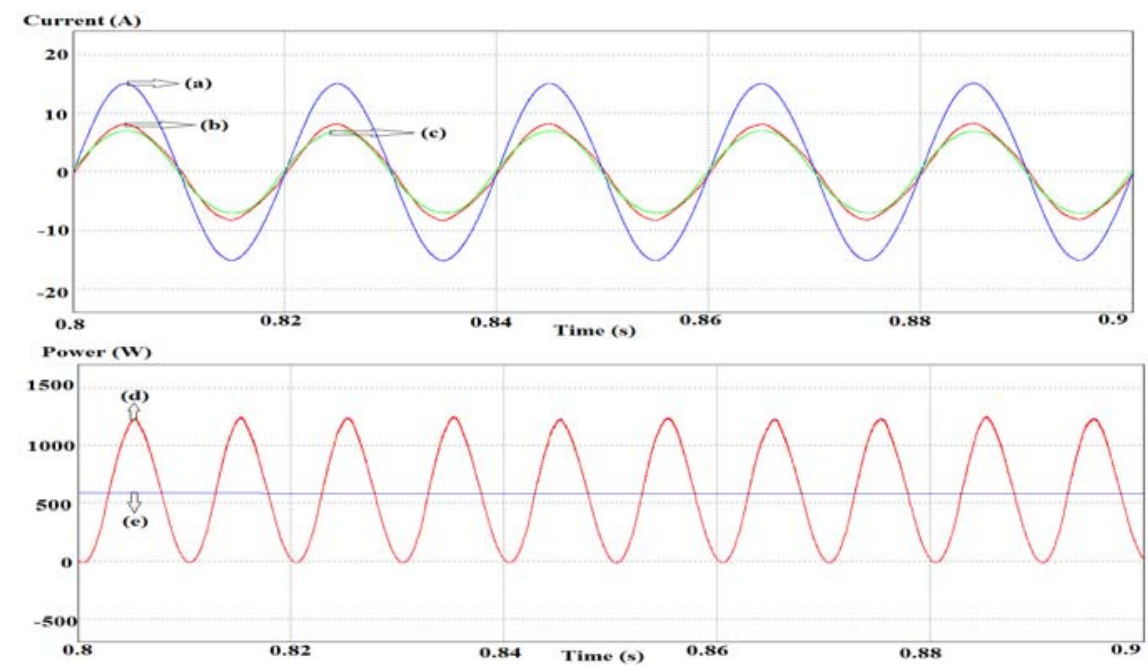

Figure 7. Simulating waveforms: (a). Load current, (b). Inverter output current, (c). Grid current, (d) Power on Buck-Boost DC-DC converter, (e) Inverter output power

When instantaneous power of five-level inverter was greater than power generated by Buck-Boost DC-DC converter, most of the power would be taken from the energy stored in the capacitor DC link for power equilibrium, so that the capacitor voltage would be decreased. The opposite condition happens, when fivelevel inverter output power less than power generated by Buck-Boost DC-DC converter, the capacitor would be increased, an equation (16), Figure 8.

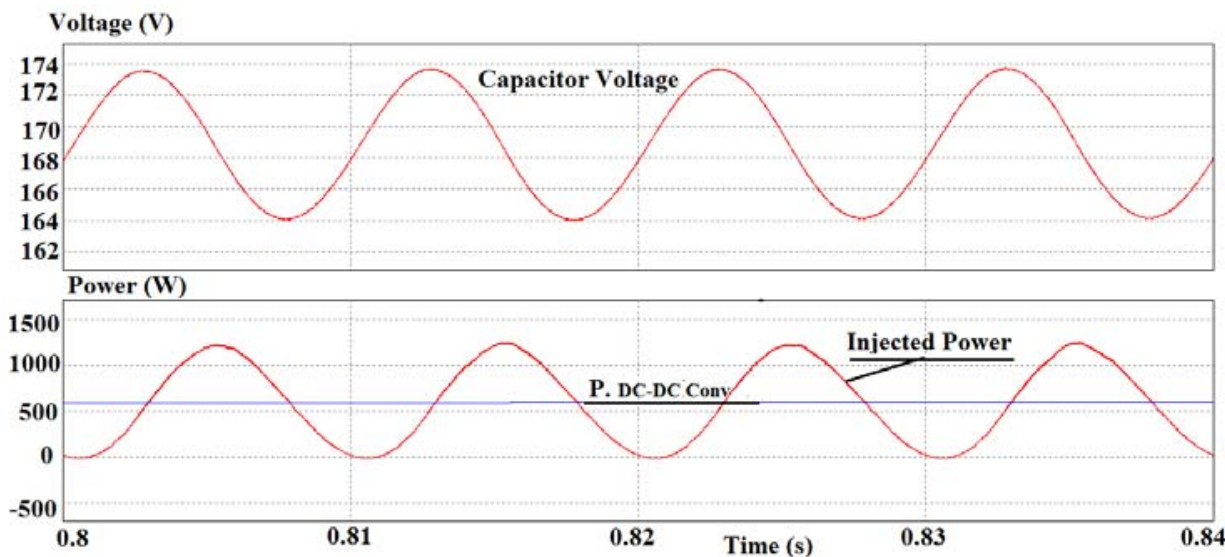

Figure 8. Capacitor voltage variation with respect to comparation between the values of $P_{D C-D C}$ and $P_{I n v}$

Impedance Matching Method in Two-Stage Converters for Single Phase PV-Grid System(L. Heru Pratomo) 
When solar irradiance under $1000 \mathrm{~W} / \mathrm{m}^{2}$ with resistive load $200 \mathrm{Ohm}$, the maximum power would be produced by PV, the required power to the load become smaller; the load power would be supplied by the power generated by PV, amount of power would be absorbed by a single phase grid source. In other hand; load and the inverter output current would be in phase, but the grid source current was dissimilar (the source current angle was $180^{\circ}$ with respect to the grid voltage), Figure 9.

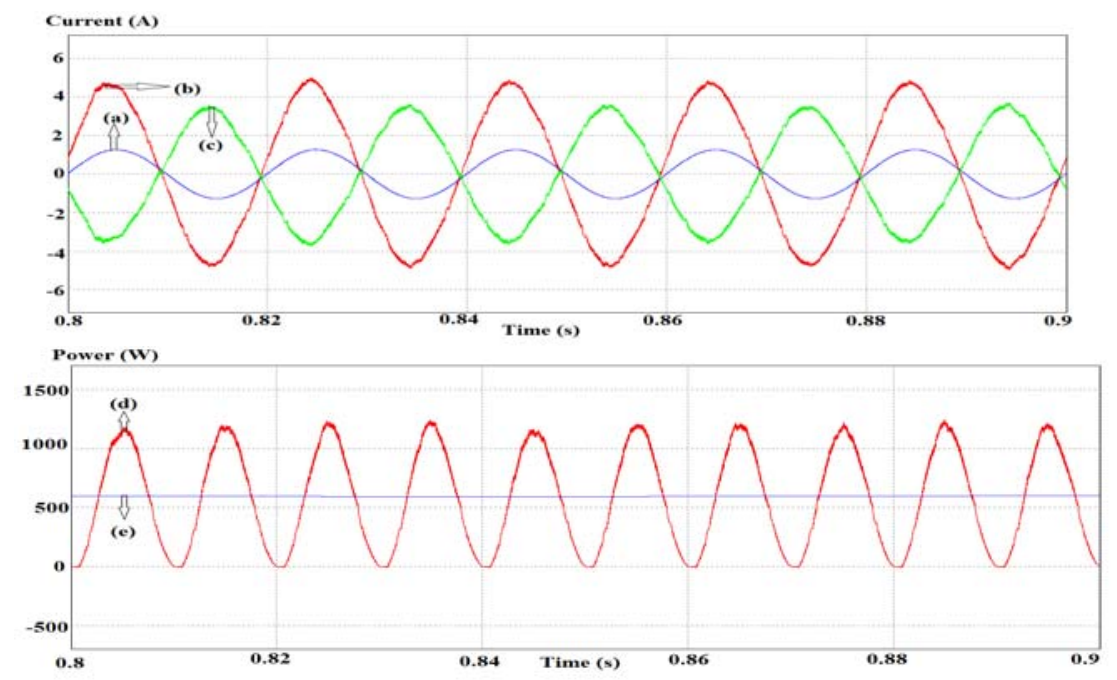

Figure 9. Simulating waveforms: (a). Load current, (b). Inverter output current, (c). Grid current, (d) Power on Buck-Boost DC-DC converter, (e) Inverter output power.

When solar irradiance drop until $250 \mathrm{~W} / \mathrm{m}^{2}$ with resistive load $200 \mathrm{Ohm}$, the maximum power would be produced by PV, the required power to the load become larger; the load power would be supplied by the power generated by $\mathrm{PV}$, there is no power would be supplied by a single phase grid source. In other hand; load and the inverter output current would be in phase, but the grid source current was nearly to zero, Figure 10.
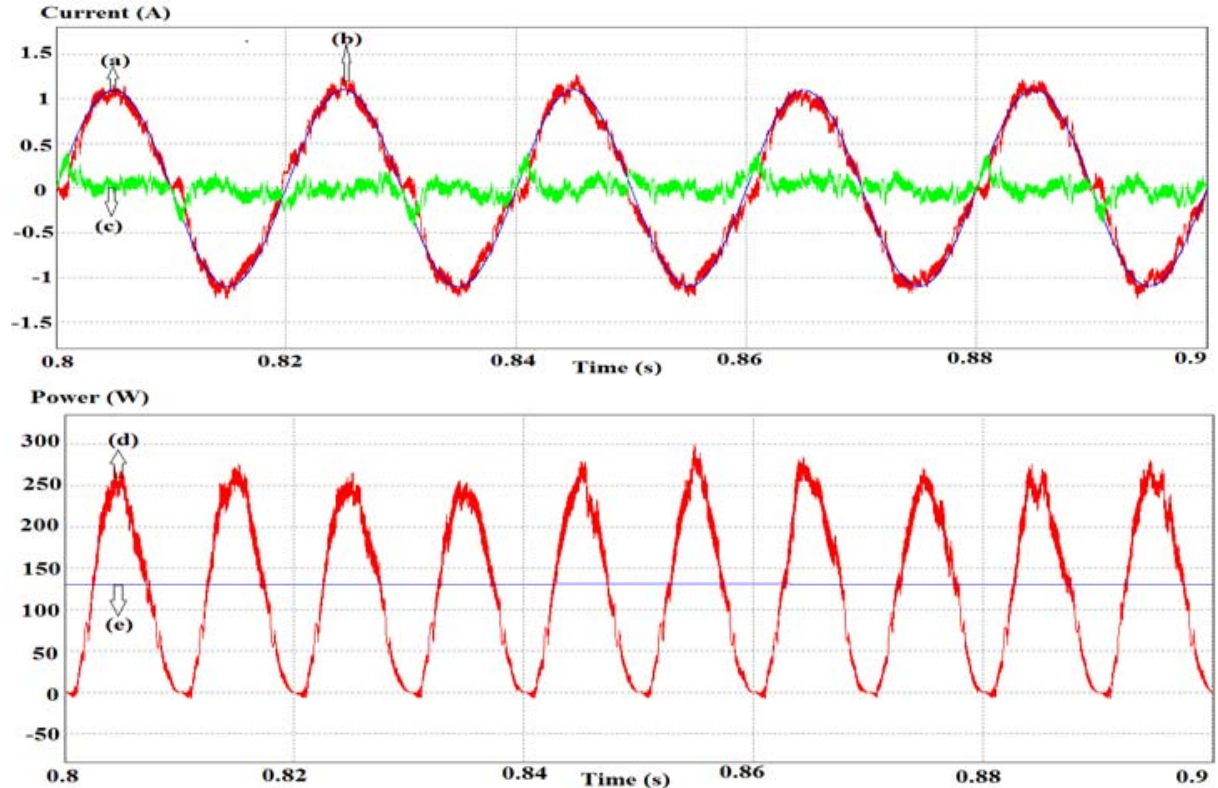

Figure 10. Simulating waveforms: (a). Load current, (b). Inverter output current, (c). Grid current, (d). Power on Buck-Boost DC-DC converter, (e). Inverter output power 
The simulated result shows that under maximum irradiance $1000 \mathrm{~W} / \mathrm{m}^{2}$ and when the solar irradiance dropped until $250 \mathrm{~W} / \mathrm{m}^{2}$, maximum power can still be produced; the output power is always equal to the PV power as seen in Figure 11 (b). The five-level inverter is still good to transmit all power generated by PV to the grid source, even though decreasing the intensity of irradiance until $250 \mathrm{~W} / \mathrm{m}^{2}$ Figure 11 (a).

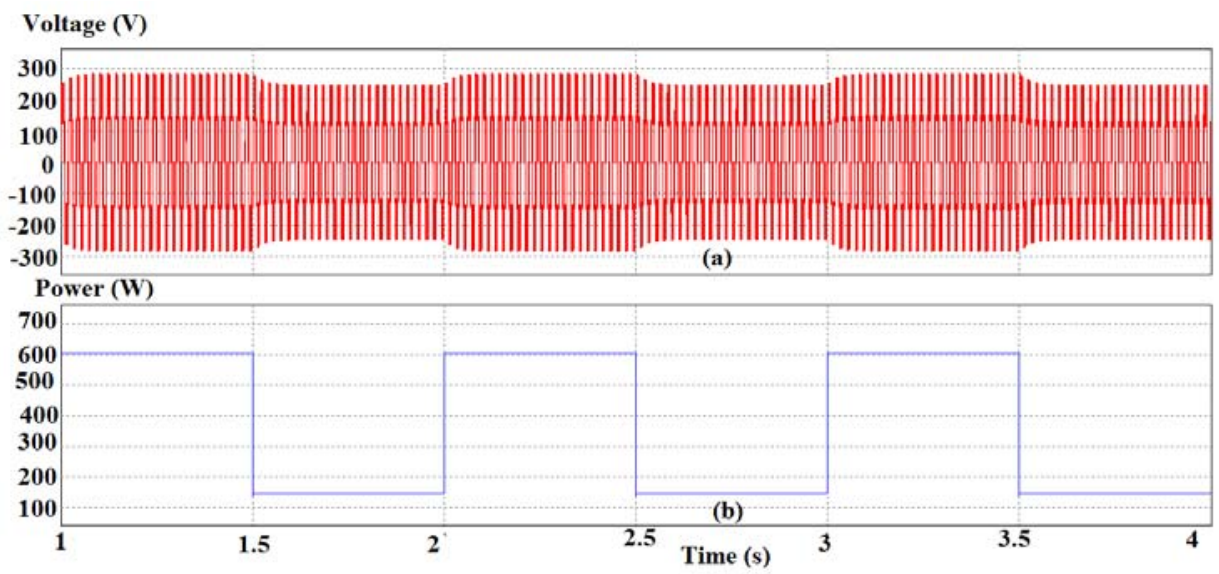

Figure 11. Simulating waveforms: (a). Inverter output voltage, (b). Power on PV and Power output PV

\section{CONCLUSION}

It is found that the impedance matching method in two-stage converters for single phase PV-grid system that has been studied ran well. It is revealed that the impedance matching control was very simple. This control scheme for five-level inverter to maximize the power generated by PV and to deliver power to the grid was derived. When the load power was large, the load power would be supplied by PV and the single phase grid source system. When the load power was small, the load power would be supplied by the PV amount of power would be absorbed by the grid source system. When the power generated by PV was equal to the load, power load power will be supplied by the PV and a grid current source close to zero. The simulated result shows that under maximum irradiance $1000 \mathrm{~W} / \mathrm{m}^{2}$ and when the solar irradiance dropped until $250 \mathrm{~W} / \mathrm{m}^{2}$, maximum power can still be produced. When the maximum power produced by the PV, the five-level inverter is still good to transmit all power generated by PV to the grid source.

\section{REFERENCES}

[1] Jun Mei, et.al., "Modular Multilevel Inverter with New Modulation Method and Its Application to Photovoltaic Grid-Connected Generator”, IEEE Trans. Power Electron, Vol. 28, No. 11, pp. 5063 - 5073, Nov 2013.

[2] Mohamed Najeh Lakhoua, et all., "System Analysis of a Hybrid Renewable Energy System”, International Journal of Electrical and Computer Engineering (IJECE), Vol. 4, No. 3, pp. 343-350, June 2014.

[3] Carrasco. J. M, et.al., "Power-Electronic Systems for The Grid Integration of Renewable Energy Sources: A survey”, IEEE Trans. Ind. Electron, Vol. 53, No. 4, pp. 1002 - 1016, Jun. 2006.

[4] Abhijit Kulkarni and Vinod John, "Mitigation of Lower Order Harmonics in a Grid-Connected Single-Phase PV Inverter”, IEEE Trans. Power Electron, Vol. 28, No. 11, pp. 5024-5037, Nov 2013.

[5] Slamet Riyadi, "Photovoltaic connection to the System through the VSI-based Flow Control for Load Sharing", Journal of Information Technology and Electrical Engineering (JITEE), Vol. 2, April 2010, pp 32-37.

[6] Nasrudin A. Rahim, and Jeyraj Selvaraj, "Multistring Five-Level Inverter With Novel PWM Control Scheme for PV Application”, IEEE Trans. Ind. Electron, Vol. 57, No. 6, pp 2111-2123, Jun 2010.

[7] Jeyraj Selvaraj and Nasrudin A. Rahim, Multilevel Inverter For Grid-Connected PV System Employing Digital PI Controller, IEEE Trans. Ind. Electron, Vol. 56, No. 1, pp 149-158, Jan 2009.

[8] Azadeh Safari et.al., "Simulation and Hardware Implementation of Incremental Conductance MPPT with Direct Control Method Using Cuk Converter”. IEEE Trans. Ind. Electron, Vol. 58, No. 4, pp 1154-1161, Apr 2011.

[9] Caston Urayai, and Gehan A.J. Amaratunga, "Single-Sensor Maximum Power Point Tracking Algorithms", IET Renew. Power Generation, Vol. 7, Iss. 1, pp. 82-88, 2013.

[10] Musa. A, et.al., "Desain and Implementation of Solar Power as battery Charger Using Incremental Conductance Current Control Method Based on dsPIC30F4012”, Proceedings of International Conference on Information Technology, Computer and Electrical Engineering, Semarang 2014, pp 323-326.

[11] Jeyraj Selvaraj and Nasrudin A. Rahim, “ Multilevel Inverter For Grid-Connected PV System Employing Digital PI Controller”, IEEE Trans. Ind. Electron, Vol. 56, No. 1, pp 149-158, Jan 2009. 
[12] Nasrudin A. Rahim, and Jeyraj Selvaraj, "Multistring Five-Level Inverter With Novel PWM Control Scheme for PV Application”, IEEE Trans. Ind. Electron, Vol. 57, NO. 6, pp 2111-2123, Jun 2010.

[13] Nasrudin A. Rahim, et.al., "Single-Phase Seven-Level Grid-Connected Inverter for Photovoltaic System”, IEEE Trans. Ind. Electron, Vol. 58, NO. 6, pp 2435-2443, Jun 2011.

[14] Jinn-Chang Wu, et.al., "New Five-Level Inverter-Based Grid-Connected Power Conversion Interface”, IET Power Electron, Vol. 6, Iss. 7, pp. 1239-1247, 2013.

[15] Jia-Min Shen, et.al., "Five-Level Inverter for Renewable Power Generation System”, IEEE Transactions on Energy Convertion, Vol. 28, No. 2, pp 257-266, Jun 2013.

[16] Slamet Riyadi, “dsPIC33 Based Control for PV-Grid System with a Buck-Boost MPPT”. TELKOMNIKA, Vol 12, No 7, pp 5137-5143, Des 2014.

[17] Leonardus Heru Pratomo, et.al., "A Simple Strategy of Controlling a Balanced Voltage Capacitor in Single Phase Five-Level Inverter”, International Journal of Power Electronics and Drive Systems (IJPEDS). Vol. 6, No. 1, pp 160-167, March 2015.

\section{BIOGRAPHIES OF AUTHORS}

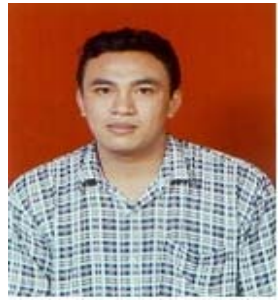

L. Heru Pratomo was born in Ambarawa, Indonesia, in 1976. He received the B.S degree and M.Eng degree from Chatolic University, Semarang, Indonesia and Bandung Institute of Technology, Bandung, Indonesia in 1994 and 2004. Now, he is on Phd Program at Gadjah Mada University. His current research is focused on multilevel inverter topology, active power filtering and PV-Grid Systems.

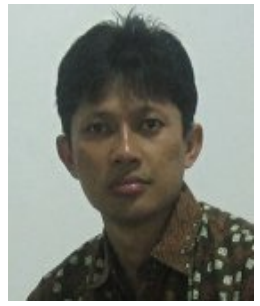

F. Danang Wijaya was born in Yogyakarta, Indonesia, in 1974. He received the B.E.E and M.E.E degrees from Gadjah Mada University, Yogyakarta, Indonesia, in 1997 and 2001. In 2006, he received Dr.Eng degree in energy sciences from Tokyo Institute of Technology, Tokyo, Japan. He has been a Lecturer and Researcher in the Electrical Engineering Department at Gadjah Mada University since 1998. His research interests are in the area of energy conversion, electrical machines, and power electronics

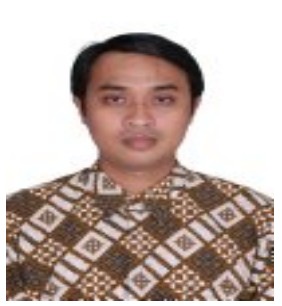

Eka Firmansyah was born in Yogyakarta, Indonesia, in 1979. He received the B.E.E from Gadjah Mada University, Yogyakarta, Indonesia, in 2001 and M. Eng degrees from Nanyang Technological University Singapore, in 2005. In 2010, he received Ph.D degree in power electronic from Kyushu University, Tokyo, Japan. He has been a Lecturer and Researcher in the Electrical Engineering Department at Gadjah Mada University since 2002. His research interests are in the area of power electronics and robotics 